\title{
Molecular Detection of the Toxin Gene toxA in Pasteurella multocida Isolated from Calves
}

\author{
Zizet Z. Zareh" ${ }^{*}$, EL Shafei AA ${ }^{2}$, Shaimaa A Abd Elkader ${ }^{2}$, Hamada Alazazy ${ }^{2}$ \\ 1 Bacteriology Department, Animal Health Research Institute, Dokki, Giza; ${ }^{2}$ Zagazig Provincial lab. of Animal \\ Health Research Institute.
}

\begin{abstract}
Pasteurella multocida (P. multocida) is frequently found in the upper respiratory tract of domestic animals as an opportunistic agent; it is the main source of an extensive range of sicknesses with universal economic importance and under predisposing management or environmental conditions which establish stress for the livestock such as climate, marketing, transport (shipping fever), change of feed, or ventilation. The present study aimed to isolate and identify the $P$. multocida organisms in calves and to investigate the antibiotic susceptibility of isolates as well as PCR-based detection of virulence gene $($ tox $A)$. A total of 168 samples were collected from calves in different farms in Ismailia and El-Dakahlia governorates, Egypt. The samples comprised 124 nasal swabs from apparently healthy and diseased calves and 44 lung samples of calves from diseased emergency-slaughtered and recently dead animals. The bacteriological investigation of the collected samples revealed 11 isolates of $P$. multocida (6.5\%). All isolates of $P$. multocida were confirmed using the VITEK2 compact system. Antibacterial assay for all the isolates detected the highest sensitivity to ciprofloxacin, gentamicin (100\% for each), and tetracycline $(81.2 \%)$ while it was resistant to amoxicillin, enrofloxacin (100\% for each), ampicillin, norfloxacin, (81.8\% for each), erythromycin (72.7\%), and streptomycin (63.6\%). Furthermore, Polymerase Chain Reaction (PCR) assays were used to detect the P. multocida tox $A$ gene. The tested isolates yielded the predicted size for the tox $A$ gene at $864 \mathrm{bp}$. In conclusion, $P$. multocida (containing tox $A$ ) was present in apparently healthy, as well as diseased/ emergency slaughtered calves. The $P$. multocida isolates were found fully resistant to amoxicillin and enrofloxacin, and susceptible to ciprofloxacin and gentamicin.
\end{abstract}

Keywords | Pasteurella multocida, calves, VITEK2 Compact system, PCR, toxA gene

Received | December 29, 2020; Accepted | January 19, 2021; Published | March 25, 2021

*Correspondence | Zizet Z Zareh, Bacteriology Department, Animal Health Research Institute, Dokki, Giza; Email: zzakaria2012@yahoo.com

Citation | Zareh ZZ, El Shafei AA, Elkader SAA, Alazazy H (2021). Molecular detection of the toxin gene toxa in pasteurella multocida isolated from calves. J. Anim. Health Prod. 9(s1): 14-19.

DOI | http://dx.doi.org/10.17582/journal.jahp/2021/9.s1.14.19

ISSN | 2308-2801

Copyright (c) 2021 Zareh et al. This is an open access article distributed under the Creative Commons Attribution License, which permits unrestricted use, distribution, and reproduction in any medium, provided the original work is properly cited.

\section{INTRODUCTION}

$P$ steurella multocida (P. multocida) is a Gram-negative bacterium that causes pasteurellosis, an acute septicemic disease with high mortality and substantial losses in livestock (Jakeen et al., 2016) and considered as a critical factor in pneumonia (Haji Hajikolaei et al., 2010). Calves of all ages are affected with $P$. multocida, however six months to two years age is highly susceptible, representing $14 \%$ of respiratory diseases in calves (Radostits et al., 2007). The organism is manifest in animals' upper respiratory tract as a normal flora; however, stress or compromised immunity makes the bacteria cause severe respiratory issues (Thorbjorg et al., 2016).

Pasteurella multocida causes many sicknesses in livestock all over the world; the most common is Hemorrhagic Septicemia (HS) (Gharibi et al., 2017). Mostly, the disease affects calves within four weeks of weaning when they are sold to various farms. Hence, it is commonly dubbed as the «Shipping fever» (Snowder et al., 2006). P. multocida outbreak showed high fever, respiratory distress, nasal discharge, polypnea, and death across the span of few days. Afterward, severe congestion in the trachea, lung, liver, and small intestine was found (Azizi et al., 2011). 
Pasteurellosis diagnosis in livestock still requires clinical manifestations, post mortem findings, and conventional bacteriological approaches that identify the causes. These methods are lengthy and hinder the differentiation between P. multocida and especially the Pasteurella haemolytica (Mannheimia haemolytica) (Berge et al., 2006; Bell, 2008). The VITEK2 technique added the bacterial screening's field by availing a speedy, economic, and highly sensitive technique for the identification of the bacteria (Wallet et al., 2005). The PCR assay is highly specific and sensitive, providing a swift revelation of $P$. multocida, without any regard to the samples' purity. Therefore, only PCR positive samples are the most effective and with a high-quality yield that could avail the isolation of the organism (Kalorey et al., 2008).

Pasteurella multocida strains with various characteristics of virulence show divergent expression of virulence genes (Yan Cheng et al., 2020). Toxigenic and nontoxigenic P. multocida isolates retain the same diagnostic biochemical morphology and reactions. It is necessary to further test laboratory isolates to classify toxigenic and nontoxigenic strains (Nagai et al., 1994).

The tox $A$ gene can be considered as a significant epidemiological marker for the characterization of $P$. multocida isolates (Aski and Tabatabaei, 2016). The tox $A$ gene is a virulence gene related to $P$. multocida; is necessary to detect pathogenic P. multocida (Varte et al., 2014). The tox $A$ gene sequence shows that detection assays for this gene, including PCR, are valid for the identification of toxigenic isolates of P. multocida (Buys et al., 1990; Peterson, 1990.

The present study aimed to isolate and identify the $P . m u l-$ tocida isolates in apparently healthy, diseased, and recently dead and slaughtered calves using a rapid and accurate technique (VITEK2 compact system) and to monitor the antibiotic susceptibility and to perform PCR-based detection of certain virulence genes $(\operatorname{tox} A)$.

\section{MATERIALS AND METHODS}

\section{Animals}

The study included diseased, dead, and apparently healthy animals at different farms in Ismailia and EL-Dakahlia governorates, Egypt. The majority of the affected cases manifested respiratory infections' symptoms such as nasal mucopurulent discharge, cough, respiratory manifestations, and fever. The experimental protocols were carried out as per guidelines of Ethics of Animal Use in Research Committee, Faculty of Veterinary Medicine, Zagazig University, Egypt.

\section{SAMPLES}

A total of 124 nasal swabs (104 were collected from diseased calves and 20 from apparently healthy ones) and 44 lung samples from disease- emergency slaughtered and recently dead calves were collected. The nasal swabs were collected from both nasal cavities. Then they were displaced in a non-nutritive transport medium, e.g., phosphate-buffered saline, where the temperature was within $4-8^{\circ} \mathrm{C}$ to stop the spoilage of samples or further over growth of bacteria. Time of transition was within 24 hours. Pneumonic lungs were packed separately in sterile plastic bags, which were then labeled and moved in an icebox to the laboratory. All samples were taken with care and ethical guidelines and biosafety measures were followed during sampling and also during working in the laboratory.

\section{BaCteriological Examination}

Nasal swabs were inoculated into a Casein Sucrose Yeast (CSY) broth for 6-8 hours, and then a loopful was cultivated onto CSY, sheep blood, and MacConkey's agar media (Oxoid,UK). Lung specimens were cultured directly onto the previously mentioned media. All agar plates were incubated at $37^{\circ} \mathrm{C}$ for 48 hours. Suspected colonies were picked up and subjected to morphological and biochemical identification. The biochemical tests included oxidase, indol, catalase, urease production, and nitrate reduction (Oxoid, UK) were performed as described previously (Quinn et al., 2011).

\section{IDENTIFICATION OF P. MULTOCIDA USING THE VITEK2 Compact System}

The P. multocida which identified by conventional method were subjected to further confirmation via the VITEK2 compact system (Biomeriux VITEK-2 Compact ref Manual - Ref-414532- France) according to the instructions of manufacturer (Pincus, 2006) as following:

Suspension preparation: An adequate number of interesting colonies of pure culture were transferred via sterile swabs, where they were suspended in $3.0 \mathrm{~mL}$ of sterile saline $(\mathrm{pH} 4.5-7.0)$ in a polystyrene $(12 \times 75 \mathrm{~mm})$ test tube. Then, the mixture was mixed well. The turbidity was adjusted to be the equal of a $0.5-0.63 \mathrm{McF}$ arland turbidity with a VITEK2 instrument DensiChek (BioMerieux, France).

Inoculation: For each isolate, the Gram-negative (GN) documentation cards were inoculated with the microorganism suspension. The isolate was identified using 47 different biochemical tests. A test tube with the suspension of microorganism was placed into a special rack (cassette) which was in turn displaced into a vacuum chamber station. Afterward the application of vacuum and introduction of air into the station, the bacterial suspension forced through the transfer tube into microchannels that fill all the test wells. 


\section{CARD SEALING AND InCUbation}

Injected cards were passed by means of cutting off the transfer tube and sealing the card before loading into the carousel incubator. All cards were raised on line at $35.5^{\circ} \mathrm{C}$ $\pm 1.0 \mathrm{C}$ for approximately six hours. During incubation, the cards were read every 15 minutes automatically. The results were got automatically and printed within 6-8 hours. All used cards were automatically dispensed into waste containers.

\section{Antimicrobial Susceptibility Testing}

All identified bacterial isolates were sub-cultured into the broth that were adjusted to be equivalent to 0.5 MacFarland turbidity, and then swabbed onto Mueller Hinton agar (Oxoid, UK) plates and then left to dry (Quinn et al., 2011). The antibiotic discs were then placed and the plates were aerobically incubated at $37^{\circ} \mathrm{C}$ for 24 hours. The zones of inhibition around the antibiotic discs were measured and interpreted according to the Clinical Laboratory Standards Institute (CLSI, 2017). The following antibiotic discs were used: amoxicillin $(10 \mu \mathrm{g})$, ampicillin $(20 \mu \mathrm{g})$, ciprofloxacin $(5 \mu \mathrm{g})$, Enrofloxacin $(5 \mu \mathrm{g})$, erythromycin $(15 \mu \mathrm{g})$, gentamicin $(10 \mu \mathrm{g})$,norfloxacin $(10 \mu \mathrm{g})$, streptomycin $(25 \mu \mathrm{g})$, tetracycline $(30 \mu \mathrm{g})$, and trimethoprim-Sulfamethoxazol $(25 \mu \mathrm{g})$ (Oxoid, UK). Drug resistance of antibiotic was calculated with MRA index according to (Rotchell and paul 2016).

\section{Detection of The TOXA Gene by PCR}

The PCR assay was carried out on the isolated strains of $P$. multocida (Tang et al., 2009) as following:

DNA Extraction: DNA was extracted from the assessed isolates via the QIAamp DNA Mini kit (Qiagen, Germany, $\mathrm{GmbH}$ ) as per the manufacturer's instructions: $200 \mu \mathrm{L}$ of the isolate suspensions were incubated with $200 \mu \mathrm{L}$ of lysis buffer and $10 \mu \mathrm{L}$ of proteinase $\mathrm{K}$ for ten minutes at a temperature of $56^{\circ} \mathrm{C}$. Then, $200 \mu \mathrm{L}$ of ethanol with a $100 \%$ concentration was introduced to the lysate. The sample was then rinsed and centrifuged as per the manufacturer's instructions. Nucleic acid was eluted with $100 \mu \mathrm{L}$ of elution buffer provided in the kit.

PCR Amplification: The tox $A$ amplification occurred in $25 \mu \mathrm{L}$ reaction volume containing Emerald Amp Max PCR Master Mix (12.5 $\mu \mathrm{L}$; Takara, Japan), $1 \mu \mathrm{L}$ of each primer (Metabion Germany) of 20 pmol concentration, $6 \mu \mathrm{l}$ of DNA template and $4.5 \mu \mathrm{L}$ of water. The reaction occurred in an applied biosystem 2720 thermal cycler. The PCR amplification was done in a thermocycler (Applied Biosystems, USA) using the thermal conditions as initial denaturation at $94^{\circ} \mathrm{C}$ for ten minutes and 35 cycles of $94^{\circ} \mathrm{C}, 48^{\circ} \mathrm{C}$ for a minute, $72^{\circ} \mathrm{C}$ for a minute each, after which a final extension occurred at $72^{\circ} \mathrm{C}$ for ten minutes
(Table 1).

Analysis of the PCR products: The PCR products were separated by electrophoresis on $1 \%$ agarose gel (Applichem, Germany, GmbH) in $1 \mathrm{x}$ TBE buffer at $40^{\circ} \mathrm{C}$ using gradients of $5 \mathrm{~V} / \mathrm{cm}$. For gel study, $15 \mu \mathrm{l}$ of the products was loaded in each gel slot. A $100 \mathrm{bp}$ plus DNA ladder (Qiagen, Germany, $\mathrm{GmbH}$ ) was adopted to know the fragment sizes. The gel was photographed by a Gel documentation system (Alpha Innotech, Biometra) and the information was evaluated via computer software.

\section{RESULTS}

Bacteriological investigation of the nasal swabs from apparently healthy calves revealed one positive sample out of 20 nasal swabs with incidence of 5.0\%; meanwhile, out of 104 nasal swabs samples of diseased calves revealed six isolates of P. multocida with incidence of $5.8 \%$. Isolates from lung tissue samples from recently dead and emergence slaughtered calves exhibited four positive samples (out of 44) with incidence of 9.1\%. A total of 11 (6.5\%) P. multocida positive samples were observed in apparently healthy, diseased, and recently dead and emergence slaughtered samples (Table 2). All colonies (11) were reinvestigated using the VITEK2 compact system and the results confirmed isolation of $11 P$. multocida isolates with an incidence of $100 \%$. A confirmatory identification by the VITEK2 compact system using Gram-negative cards was employed. The identification cards contained 47 different biochemical tests.

All the P. multocida isolates were sensitive to ciprofloxacin, gentamicin (100\% for each), and tetracycline (81.2\%) while exhibited multidrug resistance against amoxicillin, and enrofloxacin, $100 \%$ for ampicillin, norfloxacin $(81.8 \%)$, erythromycin $(72.7 \%)$, streptomycin $(63.6 \%)$, and trimethoprim- Sulphamethoxazol (54.5\%). Multi-antibiotic resistant (MAR) values greater than 0.2 means that the $P$. multocida had a high resistance to the antibiotics (Table 3). PCR assay detected tox $A$ gene in all isolates of $P$. multocida strains showed bands at $864 \mathrm{bp}$ as in (Figure 1).

\section{DISCUSSION}

Pasteurella multocida is an important pathogen hazardous to animal and human beings with a worldwide distribution (Hung et al, 2010). It causes various economical diseases in livestock all over the world, among these most common is Hemorrhagic Septicemia (Gharibi et al., 2017). Isolation rates of $P$. multocida from nasal swabs of apparently healthy calves and lung samples of diseased cases were 5.6\% and $9.1 \%$, respectively. The total isolation of $P$. multocida was 6.5\%. Previous studies reported 8.3\% (Sedeek and Thabet, 
Table 1: Primers sets sequences, target genes, amplicon sizes and cycling conditions.

\begin{tabular}{|c|c|c|c|c|c|c|c|c|}
\hline \multirow{2}{*}{$\begin{array}{l}\text { Target } \\
\text { gene }\end{array}$} & \multirow[t]{2}{*}{ Primers sequences } & \multirow{2}{*}{$\begin{array}{l}\text { Amplified } \\
\text { segment } \\
\text { (bp) }\end{array}$} & \multirow{2}{*}{$\begin{array}{l}\text { Primary } \\
\text { Denaturation }\end{array}$} & \multicolumn{3}{|c|}{ Amplification (35 cycles) } & \multirow{2}{*}{$\begin{array}{l}\text { Final } \\
\text { extension }\end{array}$} & \multirow[t]{2}{*}{ Reference } \\
\hline & & & & $\begin{array}{l}\text { Secondary } \\
\text { denaturation }\end{array}$ & Annealing & Extension & & \\
\hline \multirow[t]{2}{*}{ toxA } & $\begin{array}{l}\text { CTTAGATGAG- } \\
\text { CGACAAGG }\end{array}$ & \multirow[t]{2}{*}{864} & \multirow[t]{2}{*}{$\begin{array}{l}94^{\circ} \mathrm{C} \\
10 \text { min. }\end{array}$} & \multirow[t]{2}{*}{$\begin{array}{l}94^{\circ} \mathrm{C} \\
1 \mathrm{~min} .\end{array}$} & \multirow[t]{2}{*}{$\begin{array}{l}48^{\circ} \mathrm{C} \\
1 \mathrm{~min}\end{array}$} & \multirow[t]{2}{*}{$\begin{array}{l}72^{\circ} \mathrm{C} \\
1 \mathrm{~min} .\end{array}$} & \multirow[t]{2}{*}{$\begin{array}{l}72^{\circ} \mathrm{C} \\
10 \text { min. }\end{array}$} & \multirow[t]{2}{*}{$\begin{array}{l}\text { Tang et al. } \\
2009\end{array}$} \\
\hline & $\begin{array}{l}\text { GAATGCCA- } \\
\text { CACCTCTATAG }\end{array}$ & & & & & & & \\
\hline
\end{tabular}

Table 2: Prevalence of Pasteurella multocida isolated from apparently healthy diseased, dead and slaughtered calves

\begin{tabular}{lllllllllll} 
Samples & \multicolumn{3}{l}{$\begin{array}{l}\text { Apparently } \\
\text { Healthy calves }(\mathbf{n}=\mathbf{2 0})\end{array}$} & \multicolumn{2}{l}{$\begin{array}{l}\text { Diseased calves } \\
(\mathbf{n = 1 0 4 )}\end{array}$} & $\begin{array}{l}\text { Dead \& Slaughtered } \\
\text { calves (n=44) }\end{array}$ & \multicolumn{2}{l}{$\begin{array}{l}\text { total } \\
(\mathbf{n = 1 6 8 )}\end{array}$} \\
Type of samples & No. & No & $\%$ & No & $\%$ & No & $\%$ & No & $\%$ \\
Nasal swabs & 124 & 1 & 5.0 & 6 & 5.8 & 0 & 0 & 7 & 5.6 \\
Lung tissue & 44 & 0 & 0 & 0 & 0 & 4 & 9.1 & 4 & 9.1 \\
Total & 168 & 1 & 5.0 & 6 & 5.8 & 4 & 9.1 & 11 & 6.5
\end{tabular}

$\%$ calculated according to No. of examined sample

Table 3: Antibiogram pattern of Pasteurella multocida isolated from clinically healthy, diseased and recently dead \& slaughtered calves

\begin{tabular}{|c|c|c|}
\hline \multirow[t]{2}{*}{$\begin{array}{l}\text { Antimicrobial agent } \\
\text { (potency) }\end{array}$} & \multicolumn{2}{|c|}{$\begin{array}{l}\text { Number of } P \text {. multocida isolates } \\
\text { showing Antimicrobial suscepti- } \\
\text { bility patterns (\%) }\end{array}$} \\
\hline & Resistance & Sensitivity \\
\hline 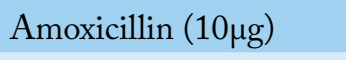 & $11(100)$ & $0(0)$ \\
\hline 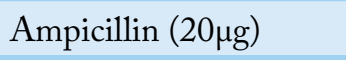 & $9(81.8)$ & $2(18.2)$ \\
\hline Ciprofloxacin $(5 \mu \mathrm{g})$ & $0(0)$ & $11(100)$ \\
\hline Enrofloxacin $(5 \mu \mathrm{g})$ & $11(100)$ & $0(0)$ \\
\hline Erythromycin $(15 \mu \mathrm{g})$ & $8(72.7)$ & $3(27.3)$ \\
\hline Gentamicin $(10 \mu \mathrm{g})$ & $0(0)$ & $11(100)$ \\
\hline Norfloxacin $(10 \mu \mathrm{g})$ & $9(81.8)$ & $2(18.2)$ \\
\hline Streptomycin $(25 \mu \mathrm{g})$ & $7(63.6)$ & $4(36.4)$ \\
\hline Tetracycline $(30 \mu \mathrm{g})$ & $2(18.2)$ & $9(81.2)$ \\
\hline $\begin{array}{l}\text { Trimethoprim-Sulpha- } \\
\text { methoxazol }(25 \mu \mathrm{g})\end{array}$ & $6(54.5)$ & $5(45.5)$ \\
\hline
\end{tabular}

2001) to $15.89 \%$ (Sayed and Zaytoun, 2009) isolation of P. multocida in Assuit Governorate Egypt, and 15\% in England (Defra, 2006). Higher incidence rates of P. multocida were obtained elsewhere in Egypt i.e., 19.23\% (Enany et al., 2012) and 22.73\% (Khadr, 2005).

The VITEK2 compact system is well known for confirmation of biochemically identified organisms. The confirmatory identification by the VITEK2 compact system was based on GN cards. The identification cards contain 47 different biochemical tests. Concluding results were yielded in roughly 6-8 hours (Pincus, 2006). All tested isolates of P. multocida were confirmed by VITEK2 compact that showed $100 \%$ positively of $P$. multocida. The VITEK2

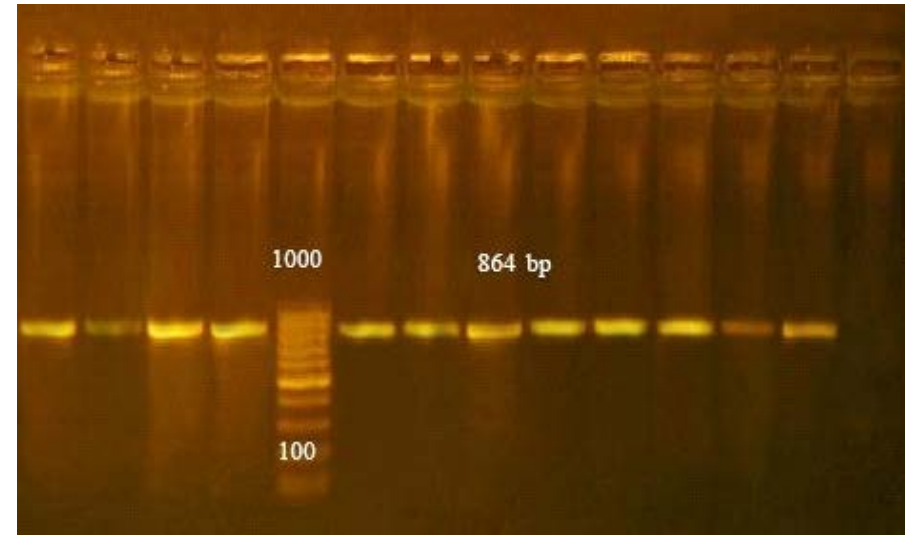

Figure 1: Agarose gel electrophoresis of PCR products of toxA gene of Pasteurella multocida isolates. PCR amplification of tox $A$ gene among the investigated isolates revealed that all isolates were positive for tox $A$ gene with amplified fragments at 864bp. Lane L: 100-1000 bp ladder as molecular size (DNA marker). Lane Pos: Control positive Pasteurella multocida. Lane Neg: Control negative. Lanes from 1 to 11: Positive Pasteurella multocida toxA gene (864 bp).

system poses quite the potential, is a highly automated novel tool for expedited identification of Gram-negative bacilli isolated from clinical specimens (Farid et al., 2014). Antibiotic utilization in bovine respiratory disease (BRD) treatment is widely used. Multidrug-Resistant (MDR) pathogens related to BRD were observed and deemed as threats to the livestock industry (Klima et al., 2014). Antimicrobial susceptibility should be perpetually monitored to curb MDR strains not that even transforms from livestock to humans (Holman et al., 2015; Klima et al., 2014). In this study, P. multocida was sensitive to ciprofloxacin and gentamicin (100\% each) and tetracycline (81.2\%). These results agree with (Khamesipour et al., 2014) and (Kumar et al., 2009; Shayegh et al., 2010) who observed 100\% sensitiv- 
OPEN OACCESS

ity of the isolated P. multocida to ciprofloxacin. The results agree as well with (Algammal et al., 2020) who reported that all the tested isolates of $P$. multocida were sensitive to gentamicin, enrofloxacin, and norfloxacin, while it exhibited a multidrug resistance against ampicillin, amoxicillin, erythromycin, and streptomycin (100\% each). The results disagree with (Varte et al., 2014) mentioned that the majority of the isolates of $P$. multocida were $100 \%$ sensitive to amoxicillin, cephalexin, chloramphenicol, ciprofloxacin, enrofloxacin, erythromycin, gentamicin, and tetracycline while it exhibited a multidrug resistance against oxytetracycline (93\%) followed by ampicillin (87\%) and amikacin (47\%). In this study, the MAR index is calculated as the ratio of the number of antibiotics to which the organism is resistant to the total number of antibiotics to which the organism is exposed. The MAR index exceeded 0.2 due to the high risk of the used antibiotics. The antimicrobial susceptibility of $P$. multocida is important to determine resistance development and help pick the appropriate antibiotics against the diseases caused by P. multocida.

Virulence factors help the pathogen colonize and invade the host, avoid defense mechanisms, injure tissues, and stimulate inflammatory responses (Ewers et al., 2004).

The tox $A$ gene is a virulence gene associated with $P . m u l-$ tocida was identified by PCR in all tested isolates. Earlier research observed that PCR targeting the tox $A$ gene is sensitive and crucial for pathogenic $P$. multocida detection (Varte et al., 2014). In the present study, all P. multocida strains showed bands at 864 bp (Figure 1). These results agree with Lichtensteiger et al. (1996). Many authors, (Ewers et al., 2006; Shayegh et al., 2010; Khamesipour et al., 2014) recorded tox $A$ genes in $P$. multocida isolates. The tox $A$ gene is not inserted into the bacterial chromosome but in a lysogenic bacteriophage that infects the agent (Pullinger et al., 2004) tox $A$ plays an important role in destruction of lung tissues, and stimulation of a noxious host inflammatory response. Therefore, the tox $A$ gene is considered an epidemiological marker found mostly in pneumonic $P$. multocida isolates (Harper et al., 2006).

\section{CONCLUSION}

From the results it could be concluded that P. multocida (containing tox $A$ ) was present in clinically healthy, diseased and recently dead or slaughtered calves in Ismailia and EL-Dakahlia governorates, Egypt. All isolates were found $100 \%$ resistant to amoxicillin and enrofloxacin, and susceptible to ciprofloxacin and gentamicin.

\section{CONFLICT OF INTEREST}

There is no conflict of interest.

\section{AUTHORS CONTRIBUTION}

All authors contributed equally.

\section{REFERENCES}

-Algammal AM, El-Sayed ME, Fatma MY, Saad SA, Elhaig MM, Hozzein WN, Ghobashy MO (2020). Prevalence, the antibiogram and the frequency of virulence genes of the most predominant bacterial pathogens incriminated in calf pneumonia Published online. https://doi.org/10.1186/ s13568-020-01037-z

-Aski HS, Tabatabaei M (2016). Occurrence of Virulenceassociated Genes in Pasteurella multocida Isolates Obtained from Different Hosts. Microbial. Pathogen.

-Azizi S, Tajbakhsh E, Rezaii A, Nekouei S, Namjoo AR (2011). The role of Mycoplasma ovipneumoniae and Mycoplasma arginini inpneumonic lungs of slaughtered sheep. Rev. Med. Vet. 162 (6): 310-315.

-Bell S (2008). Respiratory disease in sheep.2.Treatment and control. Br. Vet. Assoc. 30 (5): 278- 283. In- Practice. https:// doi.org/10.1136/inpract.30.5.278

- Berge ACB, Sischo WM, Crigmill AL (2006). Antimicrobial susceptibility patterns of respiratory tract pathogens from sheep and goat. J.A. Vet. Med. Assoc. 229 (8): 1279-1281. https://doi.org/10.2460/javma.229.8.1279

- Buys WECM, Smith HE, Kamps AMIF, Kamp EM, Smits MA. (1990). Sequance of the dermonecrotic toxin of Pasteurella multocida ssp. Multocida. Nu-cleic Acids Res. 18:2815-2816 https://doi.org/10.1093/nar/18.9.2815

- Clinical and Laboratory Standards Institute (2017). Performance Standards for Antimicrobial Susceptibility Testing: TwentyForth Informational Supplement; M100-27; CLSI:Wayne, PA, USA, 2017.

-Defra (2006).Veterinary Investigation Surveillance Report (VIDA).www. defra. gov.uk /vla /reports/docs/rep _vida _ cattle99_06.

- Enany ME, Riad EM, Wahdan A (2012). A bacterial causes of pneumonia in buffalo calves SCVMJ, XVII (2): 27-38.

-Ewers C, Lubke-Becker A, Wieler LH (2004). Pasteurella: Insights into the virulence determinants of a heterogenous bacterium. Berl. Munch. Tierarztl. Wochenschr. 9-10:367386.[PubMed] [Google Scholar]

-Ewers C, Lubke-Becker AS, Bethe A, Kiebling S, Filter M, Wieler LH (2006). Virulence genotype of Pasteurel lamultocida strains isolated from different hosts with various disease status. Vet. Microbiol. 114 (3-4): 304-314. https:// doi.org/10.1016/j.vetmic.2005.12.012

- Farid AF, Saher R Mohamed, Aziz HM, Amany N Dapg (2014). Rapid identification of Gram negative bacteria isolated from mastitic cow's milk in different dairy farms by Vitek2 compact system. Anim. Health Res. J. Special Issue for second Scientific Conference 2-6 February.

- Gharibi Mohammad R.H.H, Masoud G, Seyyedeh K Barzegar (2017). Vet. Arhiv. 87(6): 677-690. Virulence gene profiles of Pasteurella multocida strains isolated from cattle and buffalo. https://doi.org/10.24099/vet.arhiv.160727

- Haji Hajikolaei MR, Ghorbanpour M, Seyfiabad Shapouri MR, Rasooli A, Ebrahimkhani D, Jabbari AR (2010). Bacteriological and serological studies on Mannheimia haemolytica infection in cattle slaughtered 
at Ahvaz (south western Iran) abattoir. J. Vet. Res. 11: 8487 [Google Scholar]

- Harper M, Boyce JD, Adler B (2006). Pasteurella multocida pathogenesis: 125 years after Pasteur. FEMS Microbioliol. Lett. 265:1-10. [PubMed] [CrossRef] [Google Scholar] https://doi.org/10.1111/ j.1574-6968.2006.00442.x

-Holman DB, Timsit E, Alexander TW (2015). The nasopharyngeal microbiota of Feed lot cattle. Sci. Rep. 5:15557. https://doi.org/10.1038/srep15557

-Hung Y, Hung X, Tian M, Zoa N, Coa S, Wen X (2010). Identification and sequencing of two expression genes of por-cine Pasteurella multocidain vivo. J. Anim. Vet. Adv. 9 (3): 441-445. https://doi.org/10.3923/javaa.2010.441.445

-Jakeen KE,Samah SA, Soumaya AE, Ashgan MH,Abdullah AA, Moussa IM (2016). Comparative studies for serodiagnosis of haemorrhagicsepticaemia in cattle sera. Saudi J. Biol. Sci. 23: 48-53. https://doi.org/10.1016/j.sjbs.2015.06.011

-Kalorey DR, Yusuraj S, Vanjari SS, Gunjal PS, Dhanawade NB, Barbuddhe SB, Bhandarkar AG (2008). PCR analysis of Pasteurella multocida isolates from an outbreak of Pasteurellosis in Indian pigs. Comp Immunol. Microbiol. Infect. Dis. 31: 495-465. https://doi.org/10.1016/j. cimid.2007.06.003

- Khadr AM (2005). Outbreaks of pneumonia in beef calves associated with bovine viral diarrhea virus seroconversion and other respiratory pathogens. Beni-Suef Vet. Med. J. 15(2): 289-294. https://doi.org/10.21608/jvmr.2005.78024

- Khamesipour F,Momtaz H, Ma-moreh MA (2014). Occurrence of virulence factors and antimicrobial resistance in Pasteurella multocida strains isolated from slaughter cattle in Iran. Front. Microbiol. October, vol. 5 Article 536 P. 1-9. https://doi. org/10.3389/fmicb.2014.00536

-Klima CL, Zaheer R, Cook SR, Booker CW, Hendrick S, Alexander TW, McAllister TA. (2014). Pathogens of bovine respiratory disease in North American feedlots conferring multidrug resistance via integrative conjugative elements. J. Clin. Microbiol. 52:438-44

- Kumar P, Singh VP, Agrawa RK, Singh S (2009). Identification of Pasteurella multocida isolates of ruminant origin using polymerase chain reaction and their antibiogram study. Trop. Anim. Hlth. Prod. 41: 573-578. https://doi.org/10.1007/ s11250-008-9226-2

- Lichtensteiger CA, SM Steenbergen, RM Lee, DD Polson, ER Vimr (1996). Direct PCR analysis for toxigenic Pasteurella multocida. J. Clin. Microbiol. 34: 3035-3039. https://doi. org/10.1128/JCM.34.12.3035-3039.1996

- Nagai SH, Someno S, Yagihashi T (1994). Differentiation of toxigenic from non-toxigenic isolates of Pasteurella multocidaby PCR. J. Clin. Microbiol. 32(4): 1004-1010. https://doi.org/10.1128/JCM.32.4.1004-1010.1994

-Peterson SK (1990).The complete nucleotide sequence of the Pasteurella multocida toxin gene and evidence for a transcriptional repressor, Txar. Mol. Microbiol. 4: 821-830. https://doi.org/10.1111/j.1365-2958.1990.tb00652.x

-Pincus DH (2006). Microbial identification using the bioMerieux VITEK ${ }^{\circledR} 2$ System. Encyclopedia of Rapid Microbiological Methods. Bethesda, MD: Parenteral Drug Association.
- Pullinger GD, Bevir T, Lax AJ (2004). The Pasteurella multocida toxin is encoded within a lysogenic bacteriophage. Mol. Microbiol. 51: 255-269. [PubMed] [CrossRef] [Google Scholar]. https://doi.org/10.1046/j.13652958.2003.03829.x

- Quinn PJ, Markey BK, Leonard FC, Hartigan P, Fanning S, Fitz Patrick E (2011). Vet. Microbiol. Microbial. Dis. Wiley, Hoboken.

- Radostits OM, Gay CC, Hinchcliff KW, Constable PD (2007). Veterinary medicine: A textbook of the diseases of cattle, horses, sheep, pigs, and goats. 10. ed. Philadelphia: Saunders. 724-725.

-Rotchell D, Paul D (2016). Multiple Antibiotic Resistance Index. Fitness and Virulence Potential in Respiratory Pseudomonas aeruginosa from Jamaica. J. Med. Microbiol. 65: 251-271. [PubMed] [Google Scholar] https://doi. org/10.1099/jmm.0.000229

- Sayed SM, Zaitoun AMA (2009). Aerobic bacterial pathogens of pneumonic feed lot buffalo-calves in Assuit Governorate,Egypt Ass. Univ. Bull. Environ. Res. 12(1): 55-62. https://doi.org/10.21608/auber.2009.149540

-Sedeek SR, Thabet AM (2001). Some studies on bacterial causes of pneumonia in cattle in Assuit Governorate. Assuit Vet. Med. J. 45 (90): 243-255.

-Shayegh J, Atashpaz S, Salehi TZ (2010). Potential of Pasteurella multocida isolated from healthy and diseased cattle and buffaloes in induction of diseases. Bull Vet. InstPulawy. 54: 299-304

-Snowder GD, Van Vleck LD, Cundiff LV, Bennett GL (2006). Bovine respiratory disease in feedlot cattle: environmental, genetic, and economic factors. J Anim Sci. 84(8):19992008. https://doi.org/10.2527/jas.2006-046

-Tang X., Z Zhao, J Hu, B Wu, X Cai, QHe, H Chen (2009). Isolation, antimicrobial resistance and virulence genes of Pasteurella multocida strains from swine in China. J. Clinic. Microbiol. 47: 951-958. https://doi.org/10.1128/ JCM.02029-08

-Thorbjorg E, Eggert G, Olof GS, Einar J, Vala F, Gudridur ET, Sigridur H (2016). Variability of Pasteurella multocida isolated from Icelandic sheep and detection of the toxA gene. J. Med. Microbiol. 65: 897-904. https://doi.org/10.1099/ jmm.0.000306

- Varte Z, Dutta TK, Roychoudhury P, Begum J, Chandra $R$ (2014). Isolation, identification, characterization and Antibiogram of Pasteurella multocida isolated from pigs in Mizoram with special reference to progressive atrophic rhinitis. Vet. World. 7(2): 95-99. https://doi.org/10.14202/ vetworld.2014.95-99

-Wallet F, Loiez C, Renaux E, Courcol R (2005). Performances of VITEK 2 colori-metric cards for identification of gram positive and gram negative bacteria. J. Clin. Microbial. 43: 4402-4406. https://doi.org/10.1128/JCM.43.9.44024406.2005

-Yan C, Kaicheng W, Xingkai Z, Zhenle Z (2020). Differences in pathogenicity and virulence-associated gene expression among Pasteurella multocida strains with high and low virulence in a lung tissue model. Microbial. Pathogen. 140: 103911. https://doi.org/10.1016/j.micpath.2019.103911 